\title{
Influences of Country-Of-Origin on Perceived Quality \& Value According to Saudi Consumers of Vehicles
}

\author{
Osama Ahmed Abdelkader ${ }^{1}$ \\ ${ }^{1}$ University of Dammam, Kingdom of Saudi Arabia \\ Correspondence: Osama Ahmed Abdelkader, College of Applied Studies \& Community Services, University of \\ Dammam, 4049-as safa, Unit No. 1, AD DAMMAM 34221-7842, Kingdom of Saudi Arabia. E-mail: \\ osamamarketing@gmail.com
}

Received: November 9, 2014

Accepted: December 2, 2014 Online Published: January 26, 2015

doi:10.5539/ijms.v7n1p93

URL: http://dx.doi.org/10.5539/ijms.v7n1p93

\begin{abstract}
The purpose of this research is to investigate the effect of Country-Of-Origin on perceived quality \& perceived value. The hypotheses of this research cover four main cores. First, explore the significance influences of some variables on the perceptions about Country-Of-Origin. These variables include; gender, education, age, income, residence and the previous ownership. Second, study the influences of Country-Of-Origin on perceived quality $\&$ perceived value. Third, study the influence of perceived quality on perceived value. Fourth, compare the variation among the Saudi perceptions about Country-Of-Origin, perceived quality and perceived value of vehicles came from USA, Japan and Korea. The hypotheses are tested with e-survey data collected from 488 participants. According to the best of author's knowledge, this is the first study that investigates the correlations of the research structure, with the application on; "vehicles" as a large industry \& trade, "Saudi Arabia" as a big market and it includes three of the most important exporters \& producers "USA, Japan and Korea". The application of this research covers the perceptions of Saudi consumers only. The author recommends future researchers examine the relations of the research in studies focusing on other products, markets or nationalities.
\end{abstract}

Keywords: Country-Of-Origin, perceived value, perceived quality, vehicles, Saudi Arabia

\section{Introduction}

During the previous four decades, Country-Of-Origin (COO) has grown rapidly to become one of the most widely studied issues in the global marketing (Kabadayi \& Lerman, 2011; Tseng \& Balabanis, 2011). Till date there is significant amount of researches on the relations between consumer behavior and product's COO (Miranda \& Parkvithee, 2013) and it is the major focus of research (Seidenfuss et al., 2013). An example to indicate the importance of this concept; one of the most famous scientific journals such as "International Marketing Review", published a special volume focused on the COO phenomenon directly (2008, Vol. 25, No. 4) (Magnusson et al., 2011). COO image is an important extrinsic product cue, and researches show that it affects consumer perceptions, purchase intension and overall evaluations of the product (Lee \& Lee, 2011). The COO literature has consistently reported biases toward non-domestic products due to COO effects (Marti'n \& Cerviño, 2011), especially when the consumer has low knowledge with foreign brands (Moradi \& Zarei, 2012). In international environment, several studies show that $\mathrm{COO}$ influences the key dimensions of brand equity (Anisimova, 2013; Moradi \& Zarei, 2012). The literature of (Ha-Brookshire \& Yoon, 2012) shows that COO plays a major role in consumers' decision-making processes and influences how consumers view and evaluate product attributes.

Product origin has become a more complicated construct due to multi-national production relates to more than just one COO cue (Seidenfuss et al., 2013). Product may have separated dimensions such as country of assembly (COA) (Ha-Brookshire \& Yoon, 2012), country of components and parts (COC) (Ha-Brookshire \& Yoon, 2012), and country of design (COD) (Seidenfuss et al., 2013), country of brand (COB) (Anisimova, 2013) and country of manufacture (COM) (Moradi \& Zarei, 2012). Statistically significant COO effects have been documented for general products, categories of products even for certain brands. Studies prove this point, that "made in" label is very important for consumer while evaluating product (Moradi \& Zarei, 2012). Country of manufacture serves as an important informational cue in influencing decisions and purchases (Kabadayi \& Lerman, 2011). It has been 
reported that a product's country of manufacture is a more important informational cue than brand name, price and quality in shaping customer attitudes and purchasing decisions (Lee et al., 2013).

According to the findings of Diamantopoulos et al. (2011), COO image strongly influences purchase intentions through its impact on brand image that; over 60 per cent of the variance in brand image was explained by these $\mathrm{COO}$ effects and brand familiarity. Diamantopoulos et al. (2011) confirms that COO has an important indirect influence on consumers' purchase intentions. One of the examples explaining the impact of COO is that Volkswagen often uses a German-accented narrator emphasizes that its cars are "German-designed," (Magnusson et al., 2011). Another example, many consumers think differently of cars made in Sweden and Russia (Lee \& Lee, 2011). Literature of Lee \& Lee (2011) demonstrates that consumer perceptions of brands or products decrease when the $\mathrm{COO}$ changes from a developed country with a superior product category to a less advanced country with an inferior with the product category (Lee \& Lee, 2011; Abdelkader, 2011; Zolfagharian et al., 2014). So, a lot of customers think that Samsung is a Japanese brand! (Magnusson et al., 2011). While certain product categories, such as cars, perfume and electronics are strongly identified with their COO (e.g., German cars, French perfume and Japanese electronics), other product categories are not (Tseng \& Balabanis, 2011; Zolfagharian et al., 2014). Consumers show that COO has high priority for them compared with either the price or the packaging in their decision to purchase something (Moradi \& Zarei, 2012). Literature of Zolfagharian et al., (2014) concludes that consumers do use COO as an important piece of information, which exerts a significant impact on their evaluation of product quality, attitude toward the product, and purchase intention.

Wang, 2013 and Rundh, (2011), confirm that previous studies have concluded that PV has significantly influenced the purchasing intention, PQ provides added value for the consumer and PQ positively influences PV (Edward \& Sahadev, 2011). In the same context, the literature review of Wang, (2013), reports that multiple studies have found a correlation between PQ and PV. "Value" is one of the most widely and frequently used words in various disciplines of social science (O'Sullivan \& McCallig, 2012). In the marketing domain, value has been considered a key concept in understanding and predicting customer behavior (Choo et al., 2012). Customer value is the key determinant of marketing decisions (Munnukka et al., 2013). The concept of PV has become one of the most popular approaches among business managers and marketing researchers (Chen, 2013). The creation of value for customers has long been recognized as "the fundamental basis for all marketing activity" and an effective source of competitive advantage in promoting profit growth and ensuring long-term success (Chen, 2013). The majority of researchers agree that value is a trade-off between the benefits and sacrifices components (Hakola, 2013).

This research paper chose to apply on one of the largest trading (vehicles trading) and its case is one of the highest importing countries (Saudi Arabia). According to OICA, (2014) for the year 2013, the world statistics of vehicles are as following: the turnover represented 2.6 trillion USD, total investment exceeded 114 billion USD and Public Revenue about 584 billion USD. Around 77\% of vehicles imported by Saudi Arabia are passenger cars (OICA, 2014). Passenger cars are defined as "motor vehicles with at least four wheels, used for the transportation of passengers, and comprising no more than eight seats in addition to the driver's seat" (OICA, 2014). Saudi Arabia is one of the biggest and important markets in general, especially for imported vehicles. A formal survey was distributed by (MCI, 2014) among Saudi market's consumers to measure their satisfaction about the presented services by the biggest 25 agents for the variety brands of vehicles in Saudi market. The results of this survey reports that, $61 \%$ of Saudi consumers are dissatisfied about the services. The following statistics explain the importance of Saudi's vehicle market according to CDSI, (2014):

- The total imported vehicles to Saudi market in 2012 represented 982 thousand units, with 20.45 billion USD, that value equivalent $13.1 \%$ of total Saudi imports in 2012. This amount expanded in 2013 and exceeded 1.02 million units, with 21.95 billion USD, that value equivalent $13.6 \%$ of total Saudi imports in 2013.

- Total imported vehicles to Saudi market through 2009-2013 is 4.1 million units, with value 81.55 billion USD.

- The top three sources for vehicles to Saudi market between 2012-2013 are as follows: $22 \%$ from USA, $21 \%$ from South Korea and 19\% from Japan. But before 2011, Japan was the highest source.

Although, the four decades of research around the construct of $\mathrm{COO}$, but the marketing research still in-need to additional researches, with more study for different variables and with the application on a lot of diverse markets. This research paper may be a contribution in that context. 


\section{Literature \& Hypotheses}

\subsection{Country-Of-Origin $\mathrm{COO}$}

The definitions of $\mathrm{COO}$ are diverse. The previous definitions may be categorized in two categories; source-based and perception-based. The researchers who define $\mathrm{COO}$ from the source-based viewpoint, define it as the country of: "manufacture (Kabadayi \& Lerman, 2011; Martı'n \& Cervino, 2011; Ha-Brookshire \& Yoon, 2012; Zolfagharian et al., 2014), the firm's corporate headquarters (Mart1'n \& Cerviño, 2011), assembly (Ha-Brookshire \& Yoon, 2012), design, parts (Ha-Brookshire \& Yoon, 2012), and brands' entry (Ha-Brookshire \& Yoon, 2012)". In another word, "the country with which a firm is associated" (Martı'n \& Cerviño, 2011). The second category of definitions shows COO refers to "the image, reputation and stereotype (Kabadayi \& Lerman, 2011), evaluation (Lee \& Lee, 2011), facts (Mart1'n \& Cerviño, 2011) and previous public perceptions about the country's people (Moradi \& Zarei, 2012), production and marketing as a risk moderator or quality cue for consumers (Lee et al., 2013) that lead to favorable attitudes toward its products or brands (Martı'n \& Cerviño, 2011)". This research supports the second viewpoint. However, Lee \& Lee (2011), show that COO refers to consumer's attitudes about one or more of the following areas:

- Particular country in general;

- The overall of its production or

- Particular products offered by a particular country.

This research focuses on the last two of these areas. Many researchers report that, consumers prefer products made by developed countries over those from less developed countries (Lee \& Lee, 2011; Lee et al., 2013; Ha-Brookshire \& Yoon, 2012). The Global Competitive Index GCI shows the ranks of each country among the world countries (Parkvithee \& Miranda, 2012). The literature of Moradi \& Zarei, (2012), has also shown that consumer brand image changes as the brands are made in different countries. The companies which have strong brands have their products manufactured in less developed countries because of the cheap labor for competence reasons (Miranda \& Parkvithee, 2013). Nowadays, many countries may share in producing a car of any famous brand (e.g., Toyota or Ford), but a significant category of consumers show a Toyota would be still a Japanese product, just as a Ford would be an American product (Ha-Brookshire \& Yoon, 2012). The literature of Ha-Brookshire \& Yoon (2012), reports that, a more positive attitude towards foreign products among females, younger consumers and educated individuals earning high salaries. The following hypotheses cover significance testing of differences among perceptions of Saudi customers due to their demographic differences:

$H_{I}$. There are significant differences among the perceptions of Saudi customers toward COO of vehicles from USA, Japan or Korea, according to Gender.

$\mathrm{H}_{2}$. There are significant differences among the perceptions of Saudi customers toward COO of vehicles from USA, Japan or Korea, according to Age.

$H_{3}$. There are significant differences among the perceptions of Saudi customers toward $\mathrm{COO}$ of vehicles from USA, Japan or Korea, according to Education.

$H_{4}$. There are significant differences among the perceptions of Saudi customers toward COO of vehicles from USA, Japan or Korea, according to Income.

$H_{5}$. There are significant differences among the perceptions of Saudi customers toward COO of vehicles from USA, Japan or Korea, according to Residence.

$H_{6}$. There are significant differences among the perceptions of Saudi customers toward $\mathrm{COO}$ of vehicles from USA, Japan or Korea, according to Previous Usage.

$H_{7}$. There are significant overall differences among the perceptions of Saudi customers toward COO of vehicles from USA, Japan or Korea, in general.

\subsection{Perceived Quality $P Q$}

The quality of any product has two meaning, actual technical quality and PQ. Agus \& Hajinoor (2012), show that, product quality performance includes conformance, performance, reliability and durability. Erdogmus \& Turan (2012) define PQ as the consumer's judgment about the superiority of a product which is based on subjective perceptions. Parasuraman et al. (1985-1991), presented proposed models "SERVQUAL" and "SERVPERF" for the items of service's PQ as a comparison of consumer expectations with the actual performance. According to the literature of Wang (2013), there are numerous studies that suggest a positive correlation between PQ and PV. Wang (2013), reports that, PQ positively influences PV. Beneke et al. (2013), 
defines PQ as the way in which a customer views a product's brand equity and overall superiority compared to the available alternatives and the customer's attitude towards the overall brand experience as opposed to just a product's particular characteristics. The following hypothesis studies the influence of COO on PQ:

$H_{8}$. COO has a significant impact on PQ of vehicles from (USA/Japan/Korea), according to Saudi Customers.

\subsection{Perceived Value PV}

To conceptualize Customer Value construct, two main approaches can be identified in the literature. The first approach defines PV as a one-dimensional construct, while the second approach defines PV as a multi-dimensional construct (Chen, 2013). PV is difficult to both define and measure (Beneke et al., 2013). It is a highly important construct that has influences on purchase intention (Beneke et al., 2013 and Munnukka \& Jarvi, 2012). PV is one of the most important sources of competitive advantages (Mulki \& Jaramillo, 2011). Customer value, as an individual's enduring feature in the consumption context, is different from the actual value (Choo et al., 2012). Customer value as "an interactive relativistic preference experience" and it is multifaceted (Munnukka \& Jarvi, 2012). The literature of Chen (2013), suggests that PV research is still nascent and in the early stages of conceptual development. Therefore, various authors have emphasized a need for continuing research into the conceptualization of PV. Literatures show that there are four recurring characteristics of customer value: customer value is a subjective concept; trade-off between benefits and sacrifices; benefits and sacrifices can be multi-facetted and value perceptions are relative to competition (Chen, 2013). Quality has been found to be the most often investigated antecedent of value. There are structural relationships among value and other constructs (Chen, 2013). Value perceptions are thus critical to the firm given recent meta-analytic findings that demonstrate the significant impact of customer satisfaction on attitudinal loyalty and purchase intentions (Mulki \& Jaramillo, 2011).

PV as customer' assessment for price-acceptability and worth of the product (Wang, 2013). It represents an overall mental evaluation of product (Beneke et al., 2013). It includes the evaluation of product's attributes through the consumption process (Choo et al., 2012) and (Munnukka et al., 2013). The value perceptions are a cognitively-oriented appraisal that precedes customer satisfaction (Mulki \& Jaramillo, 2011). Customer satisfaction is reached when the perception of benefits received meets or exceeds expectations (Mulki \& Jaramillo, 2011). Common features of value includes the trade-off between costs and benefits (trade-off between quality and price; Rahikka et al., 2011; Choo et al., 2012; Mulki \& Jaramillo, 2011; Smith, 2013) and the overall assessment of subjective worth, while taking into consideration suitable competitor alternatives (Beneke et al., 2013). Customers get benefits, quality, worth and utility. They pay price, costs and sacrifices. The buying process of high-tech products is generally more complex, and the suppliers often do not understand how customers make their purchasing decisions (Munnukka \& Jarvi, 2012). Customer value as 'the buyers' mental trade-off between the quality and benefits they perceive in the product relative to the sacrifice they perceive by paying the price" (Munnukka \& Jarvi, 2012). Thus, PV is affected by both intrinsic and extrinsic dimensions of product quality and perceived price (Munnukka \& Jarvi, 2012). A number of researchers note customer value as the focal factor needed to be incorporated into the pricing decision process (Munnukka et al., 2013). Both suppliers and customers are generally expected to be able to determine the economic value with a relatively high accuracy (Munnukka et al., 2013). On a high level of abstraction, PV is defined as the trade-off between the benefits "what is received" and sacrifices "what is given" in a market exchange (Chen, 2013; Mulki \& Jaramillo, 2011). PV enhancement either by increasing the customer-perceived benefits or by reducing the sacrifices (Hakola, 2013). Customers come to expect a certain level of core product or service as "must haves" in their dealings with the firm and often look for "extras", firms have to add greater value to their products and services (Mulki \& Jaramillo, 2011). Benefits and costs can have both monetary and non-monetary aspects (Mulki \& Jaramillo, 2011).

There are five types of value affecting consumer decision making: functional; social; emotional; epistemic; and conditional value (Choo et al., 2012). Customer evaluates value according to five sources: information; products; interactions; environment; and ownership transfer (Choo et al., 2012). Extrinsic value consists of Consumer Return on Investment CROI which means active value, "the active investment of financial, behavioral and psychological resources that potentially yield a return", and reactive value which means service excellence (Munnukka \& Jarvi, 2012). These dimensions give rise to extrinsic benefits, in addition, perceived sacrifice. The study of Munnukka \& Jarvi (2012), suggests that, the customer value of high-tech products is constructed of five dimensions: escapism/intrinsic enjoyment; visual appeal; excellence; efficiency; and price satisfaction. Some researchers show that the customer value hierarchy is divided into two parts: desired customer value "product attributes and attribute performance, consequences in the use situation, and goals and purposes" and received customer value "attribute-based satisfaction, consequence-based satisfaction, and goal-based satisfaction" 
(Munnukka et al., 2013). The following hypotheses study the influences of COO on PV and the influences of PQ on PV:

$H_{9}$. COO has a significant influence on PV of vehicles from USA, Japan or Korea, according to Saudi Customers.

$H_{10}$. PQ has a significant influence on PV of vehicles from USA, Japan or Korea, according to Saudi Customers.

The literature confirms the importance of this research area. This paper may contribute some additions to the previous researches in the following areas:

- $\quad$ The correlation among COO, PQ and PV.

- The demographic impacts on COO.

- Study the influences of the $\mathrm{COO}$ on purchase intention of vehicles.

- Exploring Saudi's vehicle market.

- Compare the perceptions of Saudi consumers about COO for the biggest exporters of vehicles to Saudi market.

Figure 1 shows the structure of the research hypotheses as follows:

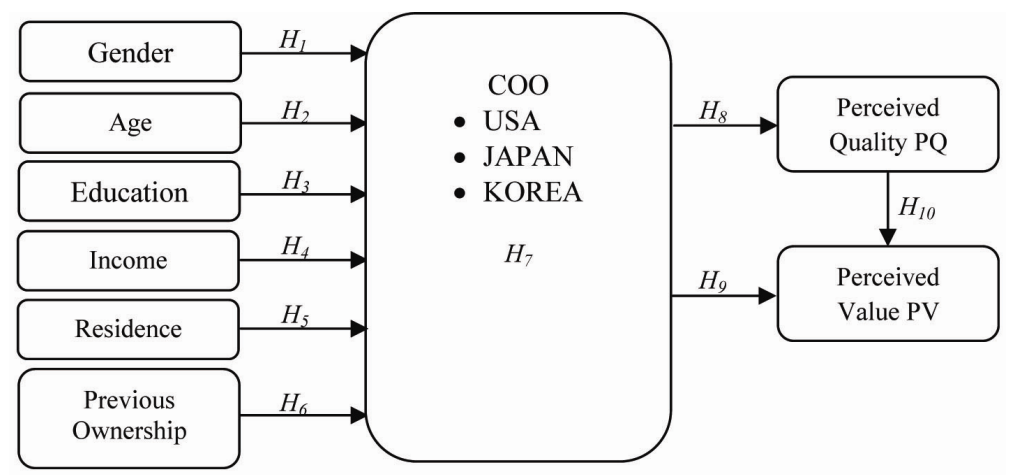

Figure 1. The structure of the research hypotheses

\section{Methodology}

\subsection{Data Generating \& Validity:}

The questionnaire was built on "Google Drive", and it was disseminated through e-Mails and the social networking sites of related vehicle' companies on "Facebook", "Twitter" and "LinkedIn". These ways of distribution were driven by earlier studies (Abdelkader, 2013a, b; Ojiako et al., 2012; Libai et al., 2010; Verhoef et al., 2010). There were three main sources to generate the items of the questionnaire. First source was the literature review for previous studies. Second one was the semi-structured interviews, that the research conducted 34 in-depth interviews with some vehicle sellers and consumers from Saudi market. Finally, there were eight experts \& academicians from related fields reviewed the primary contents of the questionnaire and suggested some changes to be more valid.

\subsection{Questionnaire Structure:}

The final structure of the questionnaire includes three dimensions, with fifteen items. All items measure the same points for each one of the three countries (USA, Japan and Korea). First dimension includes three items for measuring the perceptions about COO. Second dimension includes four items for measuring the PV. Third dimension includes nine items for measuring the PQ. An adapted item was added to each dimension to test the multi regression of the items and their significance to measure the dimension. The questionnaire based on Likert scale on a five-point scale (1 representing "Strongly Disagree" to 5 representing "Strongly Agree") for measuring the participate level of agreement for each item. A part of items was added to the questionnaire to determine the demographic data of the participates for the analysis requirements and purposes. The constructs and items are detailed through (Appendix A, Table A1). 


\subsection{Sample}

Participates of the sample received the URL of the Google-Drive' questionnaire by "e-mail" \& "Social Networks" according to the Nationality and Age which should be 18+. The URL of the e-questionnaire was available for 60 days started on the fifth April, 2014. Considering the time and resources constraints, only 488 respondents were finally selected from participates. Selection conditions are: Saudis, $18+$ years old and have/had one car at least. The sample is sufficiently large, over the recommended size of 200 cases (Jalilvand et al., 2012; Medsker, 1994). Table 1 shows the demographic description of the sample as follows:

Table 1. The sample structure

\begin{tabular}{|c|c|c|c|}
\hline \multicolumn{2}{|l|}{ Demographic Variables } & \multirow{2}{*}{$\begin{array}{l}\text { Frequency } \\
234\end{array}$} & \multirow{2}{*}{$\begin{array}{l}\text { Sample } \% \\
48\end{array}$} \\
\hline Gender & Male & & \\
\hline Gender & Female & 254 & 52 \\
\hline \multirow{3}{*}{ Age } & $18-25$ & 314 & 64.3 \\
\hline & $26-45$ & 154 & 31.6 \\
\hline & 45 and over & 20 & 4.1 \\
\hline \multirow{4}{*}{ Education } & Secondary or less & 118 & 24.2 \\
\hline & Undergraduate & 288 & 59.1 \\
\hline & Graduate & 56 & 11.4 \\
\hline & Post Graduate & 26 & 5.3 \\
\hline \multirow{5}{*}{$\begin{array}{l}\text { Monthly } \\
\text { Income }\end{array}$} & Less than $10.000 \mathrm{SR}$ & 264 & 54.1 \\
\hline & 10.000SR-14.999SR & 118 & 24.2 \\
\hline & 15.000SR-29.999SR & 84 & 17.2 \\
\hline & 30.000SR-44.999 SR & 12 & 2.5 \\
\hline & 45000SR above & 10 & 2 \\
\hline \multirow{5}{*}{ Residence } & Eastern Area & 168 & 34.4 \\
\hline & Al-Riyadh Area & 172 & 35.2 \\
\hline & Western Area & 68 & 13.9 \\
\hline & Others inside KSA & 70 & 14.3 \\
\hline & Outside KSA & 10 & 2 \\
\hline \multirow{3}{*}{ Previous Ownership } & Has/had Vehicle from USA & 322 & 66 \\
\hline & Has/had Vehicle from Japan & 314 & 64.3 \\
\hline & Has/had Vehicle from Korea & 136 & 27.9 \\
\hline
\end{tabular}

\section{Analysis \& Results}

\subsection{Reliability}

Statistical Package for Social Sciences (SPSS, V. 20) was used in this research to test the reliability by measuring Cronbach Alpha. The overall values of Cronbach Alpha is $(\alpha=0.874)$. Cronbach Alpha exceeded the critical value (0.60) suggested by Sekaran, (1992) and the value (0.70) suggested by Lee \& Shim (2006); Field (2005) and Fornell \& Larcker (1981). So, the overall reliability of the scale is acceptable. Also, all sub-scales display acceptable reliabilities, these being of the order above the generally accepted value of $(0.50)$ suggested by Hair et al. (1998) and Fornell \& Larcker (1981), and the value (0.60) suggested by Sekaran, (1992). The sub-scales values of Cronbach's $\alpha$ for each construct as follows: ( $\alpha=0.798$ for COO items), $(\alpha=0.804$ for PQ items) and ( $\alpha=0.712$ for PV items).

\subsection{Means of Items}

Table 2 shows the mean for each item of the perceptions about $\mathrm{COO} . \mathrm{COO}^{\mathrm{Japan}}$ is the highest one and $\mathrm{COO}^{\mathrm{Korea}}$ is the lowest one. The regression analysis shows the significance of the items, all of them are significant. These items are highly correlated $(\mathrm{R}=0.679$ : 0.767$)$, they could explain significant percentages of $\mathrm{COO}$ construct $\left(\mathrm{R}^{\text {Adjust }}=0.457: 0.585\right)$. 
Table 2. Means \& significance of $\mathrm{COO}$ items

\begin{tabular}{llll}
\hline \multirow{2}{*}{ Items } & \multicolumn{3}{l}{ Means } \\
\cline { 2 - 4 } & USA & Japan & Korea \\
\hline $\mathrm{COO}_{1}$ & $4.11^{*}$ & $4.61^{*}$ & $3.76^{*}$ \\
$\mathrm{COO}_{2}$ & $4.17^{*}$ & $4.54^{*}$ & $3.53^{*}$ \\
$\mathrm{COO}_{3}$ & $4.17^{*}$ & $4.52^{*}$ & $3.64^{*}$ \\
Mean & 4.15 & 4.57 & 3.64 \\
$\mathrm{R}$ & 0.679 & 0.740 & 0.767 \\
$\mathrm{R}^{\text {Adjust }}$ & 0.457 & 0.545 & 0.585 \\
\hline
\end{tabular}

(*) Significant on the significance levels $0.05,0.01$ and 0.001 .

Table 3 shows the mean for each item of the perceptions about PQ. $\mathrm{PQ}^{\mathrm{USA}}$ is the highest one and $\mathrm{PQ}^{\mathrm{Korea}}$ is the lowest one. The regression analysis shows the significance of the items, some items are not significant. The research analysis depends on the significant items only. The significant items are highly correlated $(\mathrm{R}=0.623$ : $0.657)$, they could explain significant percentages of $P Q$ construct $\left(R^{\text {Adjust }}=0.383: 0.425\right)$.

Table 3. Means \& significance of PQ items

\begin{tabular}{llll}
\hline \multirow{2}{*}{ Items } & \multicolumn{3}{l}{ Means } \\
\cline { 2 - 4 } & USA & Japan & Korea \\
\hline $\mathrm{PQ}_{1}$ & $4.12^{*}$ & $4.34^{*}$ & $3.16^{*}$ \\
$\mathrm{PQ}_{2}$ & $4.11^{*}$ & $3.95^{*}$ & 2.78 \\
$\mathrm{PQ}_{3}$ & 4.23 & 4.05 & $3.23^{*}$ \\
$\mathrm{PQ}_{4}$ & 3.37 & $4.01^{*}$ & $2.94^{*}$ \\
$\mathrm{PQ}_{5}$ & $3.95^{*}$ & 4.21 & $3.64^{*}$ \\
$\mathrm{PQ}_{6}$ & 4.00 & 4.17 & 3.57 \\
$\mathrm{PQ}_{7}$ & 4.25 & 3.68 & 3.09 \\
$\mathrm{PQ}_{8}$ & $4.27^{*}$ & 3.97 & $3.62^{*}$ \\
$\mathrm{PQ}$ & 4.22 & $4.01^{*}$ & 3.58 \\
Mean & 4.11 & 4.08 & 3.32 \\
$\mathrm{R}$ & 0.623 & 0.628 & 0.657 \\
$\mathrm{R}^{\text {Adjust }}$ & 0.383 & 0.389 & 0.425 \\
\hline
\end{tabular}

(*) Significant on the significance levels $0.05,0.01$ and 0.001 .

Table 4. shows the mean for each item of the perception about PV and $\mathrm{PV}^{\mathrm{Japan}}$ is the highest mean and $\mathrm{PV}^{\mathrm{Korea}}$ is the lowest mean. The regression analysis shows the significance of the items, all of them are significant. These items are highly correlated $(\mathrm{R}=0.564: 0.615)$, they could explain significant percentages of $\mathrm{PV}$ construct $\left(\mathrm{R}^{\text {Adjust }}\right.$ $=0.316: 0.375$ ).

Table 4. Means \& significance of PV items

\begin{tabular}{|c|c|c|c|}
\hline \multirow{2}{*}{ Items } & \multicolumn{3}{|l|}{ Means } \\
\hline & USA & Japan & Korea \\
\hline $\mathrm{PV}_{1}$ & $3.83 *$ & $4.14 *$ & $3.29 *$ \\
\hline $\mathrm{PV}_{2}$ & $3.59 *$ & $3.72 *$ & $3.20 *$ \\
\hline $\mathrm{PV}_{3}$ & $3.34 *$ & $4.11^{*}$ & $2.80^{*}$ \\
\hline Mean & 3.89 & 3.99 & 3.10 \\
\hline $\mathrm{R}$ & 0.615 & 0.564 & 0.568 \\
\hline $\mathrm{R}^{\text {Adjust }}$ & 0.375 & 0.316 & 0.320 \\
\hline
\end{tabular}

(*) Significant on the significance levels $0.05,0.01$ and 0.001 .

Table 5. shows the means of participates' perceptions in general about the constructs COO, PQ and PV for products from USA, Japan and Korea as follows: 
Table 5. The general means

\begin{tabular}{lllll}
\hline Constructs & USA & Japan & Korea & Mean \\
\hline COO & 4.15 & 4.57 & 3.64 & 4.12 \\
PQ & 4.11 & 4.08 & 3.32 & 3.84 \\
PV & 3.89 & 3.99 & 3.10 & 3.66 \\
\hline
\end{tabular}

\subsection{Hypothesis Analysis}

The research includes 10 hypotheses. The hypotheses could be categorized in four categories. First category includes the hypotheses from $\mathrm{H}_{1}$ to $\mathrm{H}_{5}$, these hypotheses test the influences of demographic variables on the perception of $\mathrm{COO}$. Second category just includes $\mathrm{H}_{6}$, this hypothesis test the influence of previous using on the perception of $\mathrm{COO}$. Third category just includes $\mathrm{H}_{7}$, this hypothesis test the variation among the three countries in general. Fourth category includes hypotheses from $\mathrm{H}_{8}$ to $\mathrm{H}_{10}$, these hypotheses test the relations among $\mathrm{COO}$, PQ and PV. The following are the results of the data analysis through (SPSS, $\mathrm{V}_{20}$ ), according to the research sample.

\subsubsection{Demographic Variables \& $\mathrm{COO}\left(\mathrm{H}_{1}\right.$ to $\left.\mathrm{H}_{5}\right)$}

The hypotheses from $\mathrm{H}_{1}$ up to $\mathrm{H}_{5}$ cover the variation analysis of $\mathrm{COO}$ perceptions among Saudi customers toward products (in general) from USA, Japan and Korea; according to demographic variables. These variables include gender, age, education, income and residence. ANOVA analysis was used to explore the differences among the sample participates according to demographic variables. Table 6 summarizes the results of ANOVA analysis for each variable as follows:

Table 6. COO \& demographic variables

\begin{tabular}{lllll}
\hline Hypotheses & Variables & USA & Japan & Korea \\
\hline $\mathrm{H}_{1}$ & Gender & $\mathrm{X}$ & $\mathrm{X}$ & Female*** \\
$\mathrm{H}_{2}$ & Age & $45-60^{* *}$ & $25-45^{* * *}$ & $25-45^{*}$ \\
$\mathrm{H}_{3}$ & Education & $\mathrm{X}$ & Graduate*** & $\mathrm{X}$ \\
$\mathrm{H}_{4}$ & Income & 45 -more* & $30-45^{* * *}$ & $\mathrm{X}$ \\
$\mathrm{H}_{5}$ & Residence & Riadh** & $\mathrm{X}$ & East** \\
\hline
\end{tabular}

(*) Significant on Level (0.05), (**) Significant on Level (0.01) and (***) Significant on Level (0.001).

- Gender $H_{1}$ : accept $\mathrm{H}_{1}$ about the differences of $\mathrm{COO}^{\mathrm{Korea}}$ according to Gender, because the mean of the females' perceptions is significantly more than the mean of males' perceptions, on the significance levels 0.05 , 0.01 and 0.001 . But, refuse $\mathrm{H}_{1}$ about the differences of $\mathrm{COO}^{\mathrm{USA}}$ and $\mathrm{COO}^{\mathrm{Japan}}$, because there are no significant differences between Males \& Females on the significance levels $0.05,0.01$ and 0.001 .

- Age $\mathrm{H}_{2}$ : accept $\mathrm{H}_{2}$, because there are significant differences among the participates' perceptions about the $\mathrm{COO}^{\mathrm{USA}}, \mathrm{COO}^{\mathrm{Japan}}$ and $\mathrm{COO}^{\mathrm{Korea}}$, according to their Age. About $\mathrm{COO}^{\mathrm{USA}}$, there are significant differences among participates' perceptions on the significance level 0.01 , the mean of age category (45 up to 60) is significantly more than the other categories. About $\mathrm{COO}^{\text {Japan }}$, there are significant differences among participates' perceptions on the significance level 0.001 , the mean of age category ( 25 up to 45 ) is significantly more than the other categories. About $\mathrm{COO}^{\mathrm{Korea}}$, there are significant differences among participates' perceptions on the significance level 0.05 , the mean of age category ( 25 up to 45 ) is significantly more than the other categories.

- Education $\mathrm{H}_{3}$ : accept $\mathrm{H}_{3}$ about $\mathrm{COO}^{\mathrm{Japan}}$, because there are significant differences among participates' perceptions on the significance level 0.001 , the mean of Graduates category is significantly more than the other categories. But, refuse $\mathrm{H}_{3}$ for the $\mathrm{COO}^{\text {USA }}$ and $\mathrm{COO}^{\text {Korea }}$, because there are no significant differences among sample' participates in their perceptions according to their Education on the significance levels $0.05,0.01$ and 0.001 .

- Income $H_{4}$ : accept $\mathrm{H}_{4}$ about $\mathrm{COO}^{\text {Japan }}$, because there are significant differences among participates' perceptions on the significance level 0.001 , the mean of income category (30.000 SR up to 44.999 SR) is significantly more than the other categories. Also, about $\mathrm{COO}^{\mathrm{USA}}$, there are significant differences among participates' perceptions on the significance level 0.05 , the mean of income category ( $45000 \mathrm{SR}$ above) is significantly more than the other categories. But, there are no significant differences among sample' participates in their perceptions about $\mathrm{COO}^{\mathrm{K} \text { orea }}$ according to their Income on the significance levels $0.05,0.01$ and 0.001 . 
- Residence $H_{5}$ : accept $\mathrm{H}_{5}$ about $\mathrm{COO}^{\text {USA }}$, because there are significant differences among participates' perceptions on the significance level 0.01 , the mean of participates' perceptions from Riyadh region is significantly more than the other regions. Also, accept $\mathrm{H}_{5}$ about $\mathrm{COO}^{\mathrm{Korea}}$, because there are significant differences among participates' perceptions on the significance level 0.01 , the mean of participates' perceptions from Eastern region is significantly more than the other regions. But, refuse $\mathrm{H}_{5}$ about $\mathrm{COO}^{\text {Japan }}$, because there are no significant differences among participates' perceptions about the $\mathrm{COO}^{\mathrm{Japan}}$ according to their Residence on the significance levels $0.05,0.01$ and 0.001 .

\subsubsection{Previous Usage Variable \& $\mathrm{COO}\left(\mathrm{H}_{6}\right)$}

Hypothesis $\mathrm{H}_{6}$ studies the differences among perceptions about $\mathrm{COO}$ according to the participates who have/had vehicles from USA, Japan or Korea and the participates who don't. ANOVA analysis confirms the acceptance of $\mathrm{H}_{6}$ about vehicles from Korea, because there are significant differences among participates' perceptions on the significance level 0.01 , the mean for participates who never had any vehicle from Korea before, is significantly more than the participates who do. Refuse $\mathrm{H}_{6}$ about vehicles from USA or Japan, because there are no significant differences among participates' perceptions, according to their previous ownership of vehicles from these countries before.

\subsubsection{General Differences among Countries $\left(\mathrm{H}_{7}\right)$}

Hypothesis $\mathrm{H}_{7}$ covers the exploring of differences among participates' perceptions, according to $\mathrm{COO}, \mathrm{PQ}$ and PV for the products (in general) from USA, Japan and Korea. ANOVA analysis was used for this test, table 7. summarizes the results of ANOVA analysis for each construct as follows:

Table 7. Differences in general

\begin{tabular}{lllll}
\hline Constructs & Country & Mean & Sig. & General Mean \\
\hline \multirow{4}{*}{ COO } & USA & 4.15 & & \\
& Japan & 4.57 & $* * *$ & 4.12 \\
& Korea & 3.64 & & \\
\multirow{2}{*}{ PQ } & USA & 4.11 & & \\
& Japan & 4.08 & $* * *$ & 3.84 \\
& Korea & 3.32 & & \\
\multirow{2}{*}{ PV } & USA & 3.89 & & \\
& Japan & 3.99 & $* * *$ & 3.66 \\
& Korea & 3.10 & & \\
\hline
\end{tabular}

(*) Significant on the significance levels $0.05,0.01$ and 0.001 .

- Accept $\mathrm{H}_{7}$, because there are significant differences among the persons' perceptions of the sample for the products from USA, Japan or Korea on the significance levels (0.05; 0.01 and 0.001).

- $\mathrm{COO}^{\mathrm{Japan}}$ are significantly more than $\mathrm{COO}^{\mathrm{USA}}$ or $\mathrm{COO}^{\mathrm{Korea}}$.

- $\mathrm{PQ}^{\mathrm{USA}}$ is significantly more than $\mathrm{PQ}^{\mathrm{Japan}}$ or $\mathrm{PQ}^{\mathrm{Korea}}$.

- $\quad \mathrm{PV}^{\mathrm{Japan}}$ is significantly more than $\mathrm{PV}^{\mathrm{USA}}$ or $\mathrm{PV}^{\mathrm{Korea}}$.

4.3.4 COO, PQ and PV Correlations $\left(\mathrm{H}_{8}, \mathrm{H}_{9}\right.$ and $\left.\mathrm{H}_{10}\right)$

Table 8 shows the results of the correlation analysis between COO/PQ, COO/PV and PQ/PV. These results are detailed in table 8 for each country separately. All correlations are significant on all significance levels $0.05,0.01$ and 0.001 . Also, table 8 shows the correlation factor $\mathrm{R}$ and the determination factor $\mathrm{R}^{\text {Adjust }}$ for each relation. The final judgment on the hypotheses $\mathrm{H}_{8}, \mathrm{H}_{9}$ and $\mathrm{H}_{10}$ on the significance levels $0.05,0.01$ and 0.001 , as follows:

- Accept $\mathrm{H}_{8}$, because there are significant influences of $\mathrm{COO}$ on PQ.

- Accept $\mathrm{H}_{9}$, because there are significant influences of $\mathrm{COO}$ on PV.

- $\quad$ Accept $\mathrm{H}_{10}$, because there are significant influences of PQ on PV. 
Table 8. Relations among COO, PQ and PV

\begin{tabular}{lllll}
\hline Relations & Country & $\mathrm{R}$ & $\mathrm{R}^{\text {Adjust }}$ & Sig. \\
\hline \multirow{3}{*}{ COO \& PQ } & USA & 0.390 & 0.150 & $* * *$ \\
& Japan & 0.501 & 0.250 & $* * *$ \\
& Korea & 0.558 & 0.310 & $* * *$ \\
\cline { 2 - 5 } COO \& PV & USA & 0.386 & 0.147 & $* * *$ \\
& Japan & 0.439 & 0.191 & $* * *$ \\
& Korea & 0.533 & 0.283 & $* * *$ \\
\cline { 2 - 5 } PQ \& PV & USA & 0.509 & 0.285 & $* * *$ \\
& Japan & 0.623 & 0.387 & $* * *$ \\
& Korea & 0.662 & 0.437 & $* * *$ \\
\hline
\end{tabular}

(*) Significant on the significance levels $0.05,0.01$ and 0.001 .

\section{Conclusions}

This research sample includes participates from vehicle' consumers of Saudi market. According to the analysis of the collected data, some of the conclusions and suggestions that can be drawn from the research are as the following:

- There are no evidences about the differences between participates who have/had vehicles from $\mathrm{COO}^{\text {USA }}$ or $\mathrm{COO}^{\mathrm{Japan}}$ and the participates who don't. There are significant differences among consumers who have/had and the participates who don't in their perceptions about $\mathrm{COO}^{\mathrm{Korea}}$, that may mean; their perception about the vehicles from $\mathrm{COO}^{\text {Korea }}$ decreased. This result about Developed/Less-developed countries variable is compatible with (Lee \& Lee, 2011 and Zolfagharian et al., 2014), but it is different from the result of (Abdelkader, 2011) which studied the image of vehicles from China according to Egyptian consumers.

- There are significant evidences of the influence of the specific image of COO on vehicles' PQ \& PV. This specific image includes the perceptions about particular-country-production in general. That result for $\mathrm{COO}^{\text {USA }}$, $\mathrm{COO}^{\mathrm{Japan}}$ and $\mathrm{COO}^{\mathrm{Korea}}$. This result about the image of particular-country-production is compatible with (Tseng \& Balabanis, 2011 and Zolfagharian et al., 2014).

- The research results confirm the significant influences of vehicles' PQ on PV for COO ${ }^{\text {USA }}, \mathrm{COO}^{\text {Japan }}$ and $\mathrm{COO}^{\mathrm{Korea}}$. This result about the influences of PQ \& PV is compatible with (Wang, 2013; Rundh, 2011 and Edward \& Sahadev, 2011).

- Marketers for products (including vehicles) from $\mathrm{COO}^{\mathrm{Korea}}$ should differ between males \& females in their marketing plans \& targeting, because females' perceptions about $\mathrm{COO}^{\mathrm{Korea}}$ are significantly better than males' perceptions. But, there are no differences between them about $\mathrm{COO}^{\mathrm{USA}}$ or $\mathrm{COO}^{\mathrm{Japan}}$. This result about the influence of the Gender variable is compatible with (Ha-Brookshire \& Yoon, 2012).

- Older consumers may tend to $\mathrm{COO}^{\text {USA }}$ vehicles, while young people may tend to $\mathrm{COO}^{\mathrm{Korea}}$ or $\mathrm{COO}^{\mathrm{Korea}}$. This result about the influence of the Age variable is compatible with (Ha-Brookshire \& Yoon, 2012).

- According to the analysis of Education variable, there are no differences among consumers' perceptions about $\mathrm{COO}^{\text {USA }}$ or $\mathrm{COO}^{\mathrm{Korea}}$, but the Graduates category is significantly better than the other categories about $\mathrm{COO}^{\mathrm{Japan}}$. This result about the influence of the Education variable is compatible with (Ha-Brookshire \& Yoon, 2012).

- The analysis of Income variable shows that the individuals earning high salaries have better perceptions about $\mathrm{COO}^{\text {USA }}$ or $\mathrm{COO}^{\mathrm{Japan}}$, but there no differences about $\mathrm{COO}^{\mathrm{Korea}}$. This result about the influence of the Income variable is compatible with (Ha-Brookshire \& Yoon, 2012).

- Academics, importers and vehicles' companies should analyze the reasons of the differences about COO ${ }^{\text {USA }}$ or $\mathrm{COO}^{\mathrm{Korea}}$, according to consumers' residences. May be there are differences between consumers who are near to the location of the firm's corporate headquarters and the other consumers who are far from them. But, there are no significant differences among them according to their residences toward vehicles' from $\mathrm{COO}^{\mathrm{Japan}}$.

- The research presents some contributions for the measurements of COO, PQ and PV for production in general or vehicles especially.

Future research should consider bigger sample size. Ideally a larger sample size would provide a clearer understanding of the relationships between the variables. Future researches should also include sample from more markets about more products from more COOs. 


\section{References}

Abdelkader, O. A. (2013a). Perceptions of Saudi Tourist about Tourism to Egypt. Business Review Cambridge, 21(2), 197-204.

Abdelkader, O. A. (2013b). Trust in Facebook Ads: a Cross-national Prospective. European Journal of Business and Management, 5(30), 98-110.

Abdelkader, O. A. (2011). Image Measurement of Chinese Passenger Cars, According to the Viewpoint of Egyptian Consumers. The Periodical of Commercial Studies, 35(4), 113-147.

Agus, A., \& Hajinoor, M. (2012). Lean production supply chain management as driver towards enhancing product quality and business performance Case study of manufacturing companies in Malaysia. International Journal of Quality \& Reliability Management, 29(1), 92-121, http://dx.doi.org/10.1108/02656711211190891

Anisimova, T. (2013). Evaluating the impact of corporate brand on consumer satisfaction. Asia Pacific Journal of Marketing and Logistics, 25(4), 561-589. http://dx.doi.org/10.1108/APJML-12-2012-0132

Beneke, J., Flynn, R., Greig, T., \& Mukaiwa, M. (2013). The influence of perceived product quality, relative price and risk on customer value and willingness to buy: a study of private label merchandise. Journal of Product \& Brand Management, 22(3), 218-228. http://dx.doi.org/10.1108/JPBM-02-2013-0262

CDSI, Central Department of Statistic \& Information. (2014). Retrieved from http://www.cdsi.gov.sa/

Chen, W. (2013). Perceived value in community supported agriculture (CSA) A preliminary conceptualization, measurement, and nomological validity. British Food Journal, 115(10), 1428-1453. http://dx.doi.org/10.1108/BFJ-01-2011-0013

Choo, H., \& Yoon, N. (2012). Luxury customer value. Journal of Fashion Marketing and Management, 16(1), 81-101. http://dx.doi.org/10.1108/13612021211203041

Cronin. J., \& Taylor S. (1992). Measuring Service Quality and Reexamination and Extension. Journal of marketing, p. 56.

Erdo, I., \& Turan, I. (2012). The role of personality congruence, PQ and prestige on ready-to-wear brand loyalty. Journal of Fashion Marketing and Management, 16(4), 399-417. http://dx.doi.org/10.1108/13612021211265818

Edward, M., \& Sahadev, S. (2011). Role of switching costs in the service quality, perceived value, customer satisfaction and customer retention linkage. Asia Pacific Journal of Marketing and Logistics, 23(3), 327-345. http://dx.doi.org/10.1108/13555851111143240

Fornell, C., \& Larcker, D. F. (1981). Evaluating structural equation models with unobservable variables and measurement error. Journal of Marketing Research, 18(1), 39-50.

Field, A. P. (2005). Discovering Statistics Using SPSS (2nd ed.). London: Sage.

Ha-Brookshire, J., \& Yoon, S. (2012). Country of origin factors influencing US consumers' perceived price for multinational products. Journal of Consumer Marketing, 29(6), 445-454. http://dx.doi.org/10.1108/07363761211259250

Hair, J. F., Anderson, R. Jr., Tatham, R. L., \& Black, W. C. (1998). Multivariate Data Analysis. Englewood Cliffs, NJ: Prentice Hall.

Hakola, J. (2013). Customer perceptions of the value of new packaging technologies. Journal of Business \& Industrial Marketing, 28(8), 649-659. http://dx.doi.org/10.1108/JBIM-07-2011-0086

Kabadayi, S., \& Lerman, D. (2011). Made in China but sold at FAO Schwarz: country-of-origin effect and $\begin{array}{llll}\text { trusting beliefs. International } & \text { Marketing }\end{array}$ http://dx.doi.org/10.1108/02651331111107125

Lee, C. P., \& Shim, J. P. (2006). An empirical study on user satisfaction with mobile business applications use and hedonism. Journal of Information Technology Theory and Application, 8(3), 57-74.

Lee, W., Phau, I., \& Roy, R. (2013). Bonds" or "Calvin Klein”, Down-under Consumer ethnocentric and brand country origin effects towards men's underwear. Journal of Fashion Marketing and Management, 17(1), 65-84. http://dx.doi.org/10.1108/13612021311305146 
Lee, H., \& Lee, C. (2011). Country-of-origin and brand redeployment impact after brand acquisition. Journal of Consumer Marketing, 28(6), 412-420. http://dx.doi.org/10.1108/07363761111165921

Li, N., \& Murphy, W. (2013). Prior consumer satisfaction and alliance encounter satisfaction attributions. Journal of Consumer Marketing, 30(4), 371-381. http://dx.doi.org/10.1108/JCM-05-2013-0569

Martin, O., \& Cervino, J. (2011). Towards an integrative framework of brand country of origin recognition determinants A cross-classified hierarchical model. International Marketing Review, 28(6), 530-558. http://dx.doi.org/10.1108/02651331111181402

MCI, Ministry of Commerce \& Industry, Saudi Arabia. (2014). Retrieved from http://www.mci.gov.sa/Pages/Default.aspx

Munnukka, J., \& Jarvi, P. (2012). The price-category effect and the formation of customer value of high-tech products. Journal of Consumer Marketing, 29(4), 293-301. http://dx.doi.org/10.1108/07363761211237362

Munnukka, J., Jarvi, P., \& Outi, U. (2013). Impact of service quality dimensions on the formation of customer value in B to B services. Marketing Intelligence \& Planning, 31(3), 286-299. http://dx.doi.org/10.1108/02634501311324627

Mulki, P., \& Jaramillo, F. (2011). Ethical reputation and value received: customer perceptions. International Journal of Bank Marketing, 29(5), 358-372. http://dx.doi.org/10.1108/02652321111152891

Miranda, M., \& Parkvithee, N. (2013). The influence of social class on the perceptions of country of origin National brands produced in overseas locations. Marketing Intelligence \& Planning, 31(4), 388-404. http://dx.doi.org/10.1108/02634501311324861

Magnusson, P., Stanford, A., \& Zdravkovic, S. (2011). What? I thought Samsung was Japanese”: accurate or not, perceived country of origin matters. International Marketing Review, 28(5), 454-472. http://dx.doi.org/10.1108/02651331111167589

Moradi, H., \& Zarei, A. (2012). Creating consumer-based brand equity for young Iranian consumers via country of origin sub-components effects. Asia Pacific Journal of Marketing and Logistics, 24(3), 394-413, http://dx.doi.org/10.1108/13555851211237885

OICA, Organisation Internationale des Constructeurs d'Automobiles. (2014). Retrieved from http://www.oica.net/

O'Sullivan \& McCallig, J. (2012). Customer satisfaction, earnings and firm value. European Journal of Marketing, 46(6), 827-843. http://dx.doi.org/10.1108/03090561211214627

Parasuraman, A., Zeithaml, V. A., \& Berry, L. L. (1985). A conceptual model of services quality and its implication for future research. Journal of Marketing, 49(4), 41-50.

Parasuraman, A., Zeithaml V. A., \& Berry, L. L. (1988). SERVQUAL: A multiple-item scale for measuring consumer perceptions of service quality. Journal of Retailing, 64(1), 12-40.

Parasuraman, A., Berry, L. L., \& Zeithaml, V. A. (1991). Refinement and Reassessment of the SERVQUAL Scale. Journal of Retailing, 67(Winter), 420-450.

Parasuraman, A., Zeithaml, V. A., \& Berry, L. L. (1994a). Reassessment of Expectations as a comparison standards in measuring service quality: implications for further research. Journal of Marketing, 58(2), 111-124.

Parasuraman, A., Zeithaml, V. A., \& Berry, L. L. (1994b). SERVQUAL: Alternative scales for measuring service quality? A comparative assessment based on psychometric and diagnostic criteria. Journal of Retailing, 70(1), 193-199.

Rundh, B. (2011). Development of customer value in a supply chain: managerial thinking about strategic marketing. Journal of Business \& Industrial Marketing, 26(4), 260-272. http://dx.doi.org/10.1108/08858621111127009

Rahikka, E., Ulkuniemi, P., \& Pekkarinen, S. (2011). Developing the value perception of the business customer through service modularity. Journal of Business \& Industrial Marketing, 26(5), 357-367. http://dx.doi.org/10.1108/08858621111144415

Seidenfuss, K., Kathawala, Y., \& Dinnie, K. (2013). THEME ARTICLES: BRANDING IN ASIA Regional and country ethnocentrism: broadening ASEAN origin perspectives. Asia Pacific Journal of Marketing and Logistics, 25(2), 298-320. http://dx.doi.org/10.1108/13555851311314077 
Sekaran, U. (1992). Research Methods for Business: a skill building approach (2nd ed.). New York: John Willey and Sons.

Smith, A. (2013). The value co-destruction process: a customer resource perspective. European Journal of Marketing, 47(11/12), 1889-1909. http://dx.doi.org/10.1108/EJM-08-2011-0420

Parkvithee, N., \& Miranda, M. (2012). The interaction effect of country-of-origin, brand equity and purchase involvement on consumer purchase intentions of clothing labels. Asia Pacific Journal of Marketing and Logistics, 24(1), 7-22. http://dx.doi.org/10.1108/13555851211192678

Tseng, T., \& Balabanis, G. (2011). Explaining the product-specificity of country-of-origin effects", International Marketing Review, 28(6), 581-600. http://dx.doi.org/10.1108/02651331111181420

Wang, E. (2013). The influence of visual packaging design on Perceived food product quality, value, and brand preference. International Journal of Retail \& Distribution Management, 41(10), 805-816. http://dx.doi.org/10.1108/IJRDM-12-2012-0113

Zolfagharian, M., Saldivar, R., \& Sun, Q. (2014). Ethnocentrism and country of origin effects among immigrant consumers. Journal of Consumer Marketing, 31(1), 68-84. http://dx.doi.org/10.1108/JCM-06-2013-0620

\section{Appendix A}

Table A1. Constructs and items

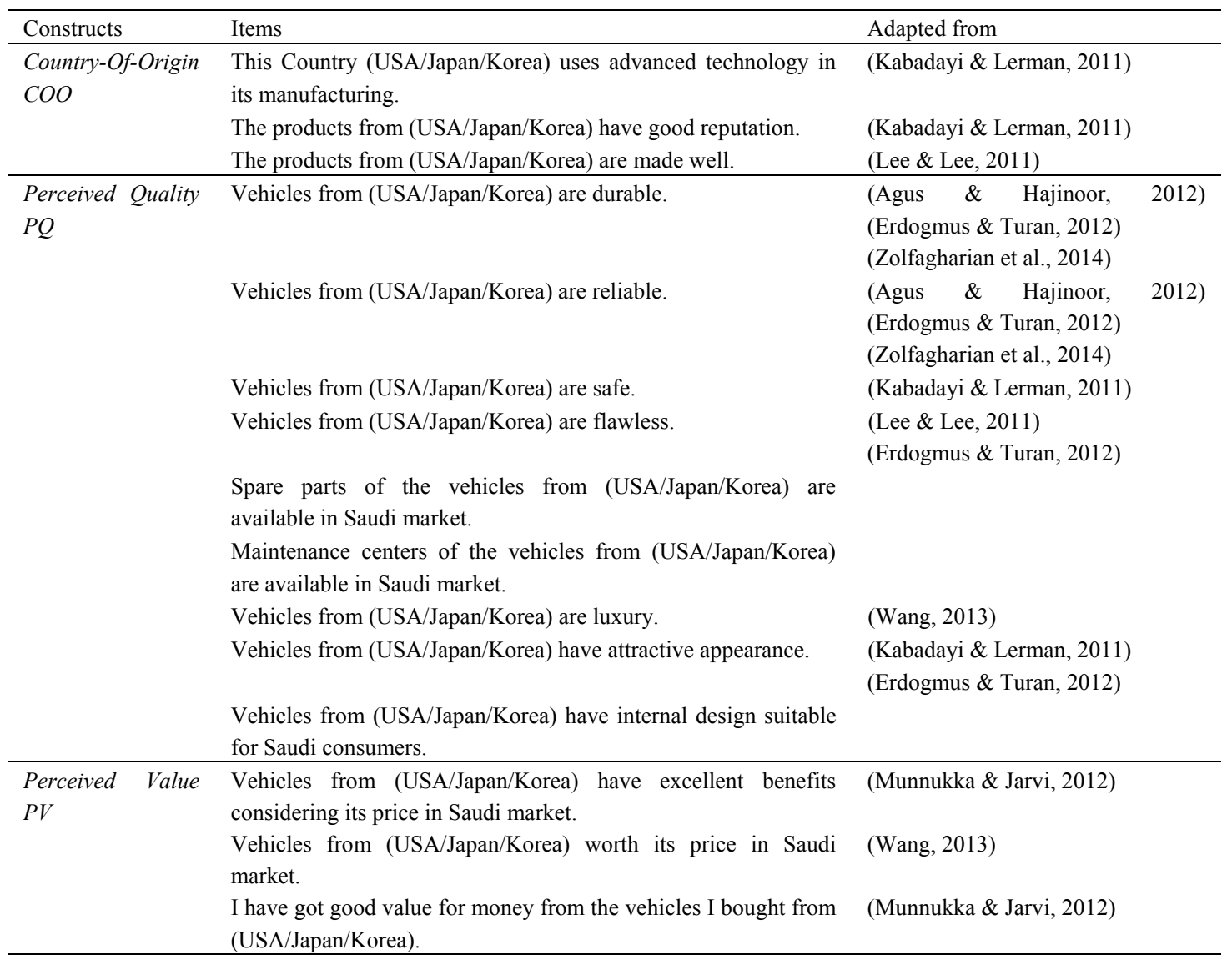

\section{Copyrights}

Copyright for this article is retained by the author(s), with first publication rights granted to the journal.

This is an open-access article distributed under the terms and conditions of the Creative Commons Attribution license (http://creativecommons.org/licenses/by/3.0/). 